\title{
New psychoactive and classic substances in pooled urine samples collected at the Ultra Europe festival in Split, Croatia
}

\author{
Davorka Sutlović ${ }^{1,2}$, Sendi Kuret ${ }^{1}$, and Marija Definis ${ }^{3,4}$ \\ ${ }^{1}$ University of Split, Department of Health Studies, Split, Croatia \\ ${ }^{2}$ University of Split School of Medicine, Department of Toxicology and Pharmacogenetics, Split, Croatia \\ ${ }^{3}$ University Hospital Centre Split, Department of Pathology and Forensic Medicine, Split, Croatia \\ ${ }^{4}$ University of Split School of Medicine, Department of Forensic Medicine, Split, Croatia
}

[Received in November 2020; Similarity Check in November 2020; Accepted in September 2021]

\begin{abstract}
We believe that analysing pooled urine samples for recreational drugs used at mass events can provide useful information about trends in drug use. An opportunity arose with the Ultra Europe music festival, which is attended by more than 150,000 people from over 150 countries every year. We analysed 30 pooled urine samples collected from portable chemical toilets located at or close to the Ultra Europe music festival venue in Split, Croatia in 2016-2018 to detect the presence of classic and new psychoactive substances (NPS). Four urine samples collected in 2016 were from a toilet without added chemicals (otherwise used to kill the smell) while the remaining samples were collected from toilets with added chemicals. Samples were qualitatively analysed with gas chromatography-mass spectrometry (GC/MS) using the fullscan mode. Data were compared with the Wiley mass spectral library of designer drugs and our in-house library containing about 1000 compounds and metabolites. We identified forty-six different substances and metabolites, 26 of which were classic substances/metabolites, mostly from the stimulants group, while 20 were NPS. In the NPS group, most of them were phenethylamines and cathinones. The variety of substances was the highest on the first day of the festival regardless of the year, but 2018 showed a significant drop compared to the previous two years. The results of our study revealed a stable trend of classic drug consumption, while NPS trend changed from one year to another.
\end{abstract}

KEY WORDS: amphetamines; cathinones; music festival; portable chemical toilet; recreational drugs

The term new psychoactive substances (NPS), according to the United Nations Office on Drugs and Crime, denotes "substances of abuse, either in a pure form or a preparation, that are not controlled by the 1961 Single Convention on Narcotic Drugs or the 1971 Convention on Psychotropic Substances, but which may pose a public health threat" (1). On the market they are referred to as "legal highs", "bath salts", or "research chemicals" and are known to affect mental health, behaviour, and perception (2). They are analogues or chemical derivatives of controlled drugs designed to achieve similar effects to those of illegal ones but still have not been listed as such $(2,3)$. Their use is most common among young recreational users and is constantly increasing $(3,4)$. Presently, many countries are experimenting with a number of control measures to address this issue, which is why any information on the trends of their use is welcome.

According to online forums, people consume NPS at electronic music festivals to enhance their musical experience. There are reports of an increasing number of acute intoxications at music festivals in the Netherlands (4) and nightclubs, bars, and disco clubs in central London,

Corresponding author: Davorka Sutlović, University of Split, Department of Health Studies, Ruđera Boškovića 35, 21000 Split, Croatia, E-mail:dsutlovic@ozs.unist.hr which confirm the presence of both classical drugs and NPS $(5,6)$. The latter two studies point to the utility of urine sample analysis to evaluate NPS consumption. Similar tests have been performed on pooled urine samples taken at music festivals in Belgium and the UK (7), while an analysis in Poland, carried out on wastewater samples, also showed a rise in popularity of NPS there (8).

Ultra Europe held in Split, Croatia each summer since 2013 has been the largest electronic music festival in Europe. According to organizers and the media, it has the audience of about 150,000 people from more than 150 countries every year and takes pride in being "... one of the key weeks in the continent's dance music calendar", according to its official website. As in other countries, this festival has been connected with increasing availability, possession, and distribution of illegal drugs. As we did not have any official data about NPS use at the festival, we asked the Croatian Ministry of Internal Affairs for more detail. They reported back that the police seized 1100 pieces of ecstasy, 73 pieces and $92.5 \mathrm{~g}$ of MDMA, 13 pieces and $79.8 \mathrm{~g}$ of amphetamine, $253.4 \mathrm{~g}$ of marijuana, $12.5 \mathrm{~g}$ of hashish, $34.1 \mathrm{~g}$ of cocaine, and $1.7 \mathrm{~g}$ of ketamine in 2016 alone. In 2017, the police seized 1097 pieces of ecstasy, $39.27 \mathrm{~g}$ of MDMA, $105.93 \mathrm{~g}$ of amphetamine, $342.19 \mathrm{~g}$ of marijuana, $0.85 \mathrm{~g}$ of hashish, $13.31 \mathrm{~g}$ of cocaine, three pieces 
of LSD, and $0.72 \mathrm{~g}$ of heroin. The report from 2018 referred only to seizure of a large amount of marijuana, $49 \mathrm{~kg}$.

Considering that NPS consumption seems to increase worldwide and that no NPS were reported by the police, we decided to identify the trends at the Split Ultra, hoping to get more accurate information about what was actually being consumed.

\section{MATERIALS AND METHODS}

\section{Sample collection}

Until 2019, the main event would take place at the city's football stadium (Figure 1A, upper left corner), last three days, and then the festival would move on to the nearby Dalmatian islands for another couple of days.

Our first urine sampling in 2016 (16-18 July) was arranged with the organiser to take place inside the stadium, but one chemical toilet was (mis)placed on the main road connecting the city centre with the stadium (Figure 1A, location 1) and had no chemicals, while the other, which contained added chemical agents, was placed close to the stadium (Figure 1A, location 2). Each had a 265 L capacity and no rinse system to dilute urine. The assumption was that the toilets would mostly be used by the festival audience but also by those who did not enter the stadium at all, such as youth gathering around the stadium to listen to music. The musical part of the festival was scheduled to take place from $5 \mathrm{pm}$ to 5 am every day, and the toilets were emptied and cleansed at 7 every morning. However, the first day was cancelled over stormy weather, which is why only the toilets outside the stadium were available for use, and we collected one sample per toilet only once that day. On the second day, the organiser decided to start the programme earlier $(1 \mathrm{pm})$ to compensate for the lost time. We took two samples from both locations, one at the start and the other at the end of the event. On the last day, samples were taken after the festival had ended, which makes eight collected samples in total, four from either toilet (Table 1).

In 2017, sampling from four toilets with added chemicals placed at three locations by the stadium (Figure 1B) was scheduled to take place once a day at 2 am (Table 1), but on the second and the third day one of the two toilets at location 3 was out of commission, which is why we collected only ten urine samples.

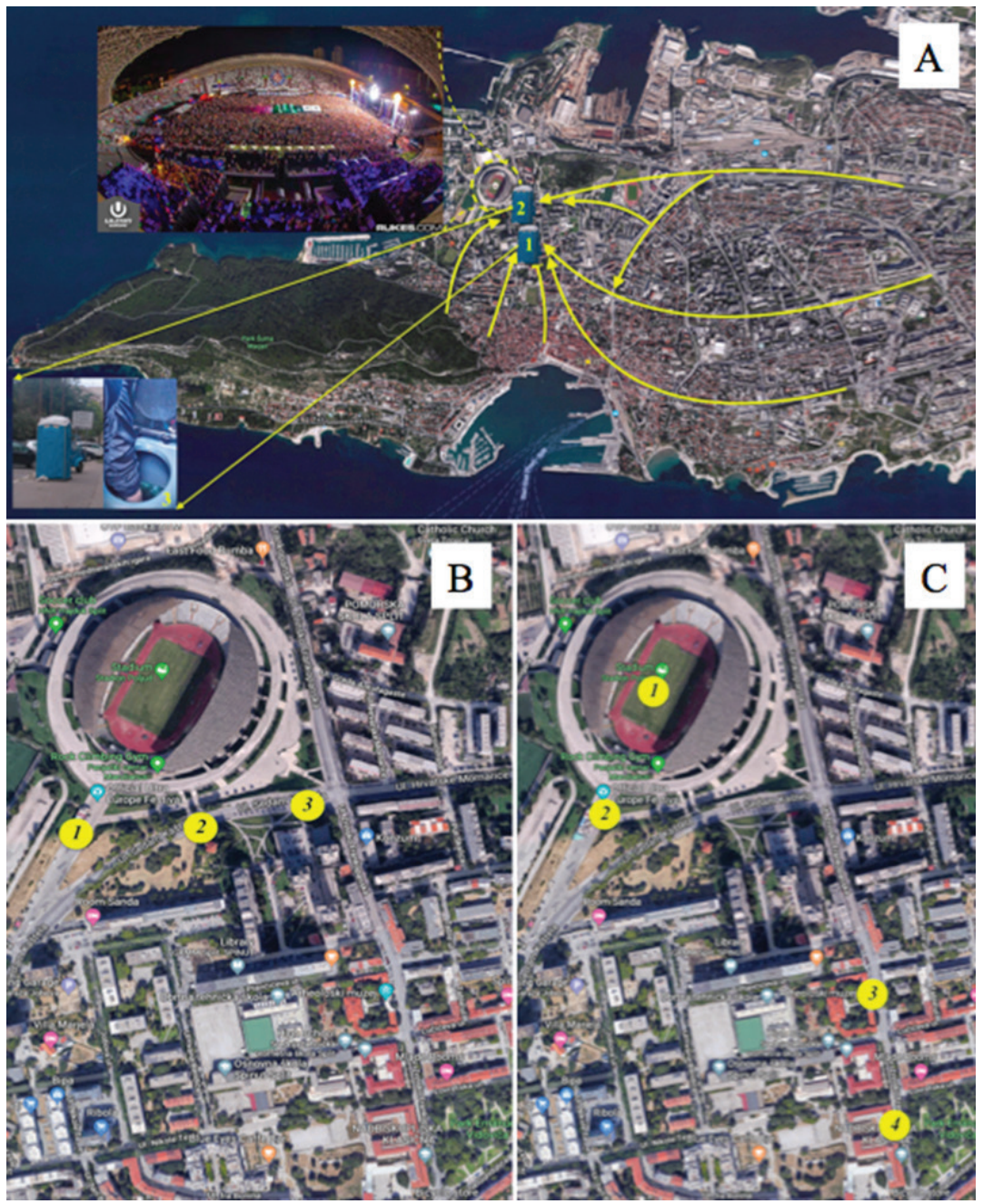

Figure 1 Location of the sampled chemical toilets during the Split Ultra music festival in 2016 (A), 2017 (B), and 2018 (C) 
In 2018, the organiser let us enter the stadium. Twelve samples were taken from toilets with added chemicals at four locations: three from three toilets placed inside the stadium, five from five toilets located next to the stadium, and four samples from three toilets a bit further away from the stadium (Figure $1 \mathrm{C}$ ). All but the inside-the-stadium samples were taken once at 4 am (Table 1). At location 3 one sample was taken on the first day of the festival and two samples on the second day, while only one sample was taken at location 4 (on the second day), which was the farthest away from the stadium.

All urine samples were taken with syringes directly from the toilets and transferred to $100 \mathrm{~mL}$ containers (Figure 1A - lower left corner), delivered to the laboratory, and stored at $-20{ }^{\circ} \mathrm{C}$ within $6 \mathrm{~h}$. Overall, 30 samples were analysed (Table 1).

\section{Methods}

The analysis was done according to the laboratory protocol and the protocols described by Vaiano et al. ( 9 , 10). Solid-phase extraction was performed using the Supelclean Envi Florisil and Supelclean LC-18 for reversedphase extraction (Supelco, Sigma Aldrich, Taufkirchen, Germany). For liquid-liquid extraction we used TOXI Tubes A (Varian, Palo Alto, CA, USA). Drugs were qualitatively analysed with a Shimadzu GC/MS-QP2010 Ultra (Shimadzu, Kyoto, Japan) gas chromatograph with mass spectrometer using the full-scan mode ( $\mathrm{m} / \mathrm{z}$ range $40-600)$. The chromatographic column was InterCap 5MS/NP (5\% phenyl-95\% methyl polysiloxane, length $30 \mathrm{~m}$, diameter $0.25 \mathrm{~mm}$, film thickness $0.25 \mu \mathrm{m}$ ). The initial column temperature of $90^{\circ} \mathrm{C}$ was held for $3 \mathrm{~min}$, then increased to $270{ }^{\circ} \mathrm{C}$ at $15^{\circ} \mathrm{C} / \mathrm{min}$ and held there for $5 \mathrm{~min}$, and then increased to $320^{\circ} \mathrm{C}$ at $15^{\circ} \mathrm{C} / \mathrm{min}$ and held there for $27 \mathrm{~min}$. The total run time was $50.33 \mathrm{~min}$. Ultra-pure grade helium was used as a carrier gas at the flow rate of about $1.5 \mathrm{~mL} /$ $\min$.

The obtained data were compared with the Wiley mass spectra library of designer drugs (DD2015), the SWGDRUG free database, and our own in-house library containing about 1000 compounds and metabolites $(11,12)$. Each sample was analysed twice.

\section{RESULTS}

Table 2 shows the findings for 18 samples collected in 2016 and 2017. Nineteen substances were identified as NPS and 25 as classic substances. Most (11 classic and 7 NPS) were found in sample 1 from 2016, which was taken from the toilet with added chemicals on the first night when the festival was not held. Between 4 and 18 substances were found in other urine samples. In two samples from 2016, taken from the toilet with added chemicals, NPS were not found (Figure 2). In 2017, 19 classic and 13 NPS were identified, most of which in sample 1 ( 9 classic and 7 NPS) and 4 (7 classic and 8 NPS) (Figure 2). In addition, all 2016 and in 2017 samples showed the presence of caffeine,

Table 1 Location and time of urine sampling at the Split Ultra festival by day

\begin{tabular}{|c|c|c|c|c|}
\hline 2016 & $\begin{array}{c}\text { Day } 1 \\
\text { Friday/Saturday }\end{array}$ & \multicolumn{2}{|c|}{$\begin{array}{c}\text { Day } 2 \\
\text { Saturday/Sunday } \\
(\mathbf{1 3} \mathrm{pm}-\mathbf{5} \mathrm{am})\end{array}$} & $\begin{array}{c}\text { Day } 3 \\
\text { Sunday/Monday } \\
(17 \mathrm{pm}-5 \mathrm{am})\end{array}$ \\
\hline Collection time & $1 \mathrm{am}$ & $2 \mathrm{pm}$ & $6 \mathrm{am}$ & $6 \mathrm{am}$ \\
\hline Location 1 & sample $1^{\mathrm{a}}$ & sample $2^{\mathrm{a}}$ & sample $3^{a}$ & sample $4^{\mathrm{a}}$ \\
\hline Location 2 & sample 1 & sample 2 & sample 3 & sample 4 \\
\hline 2017 & $\begin{array}{c}\text { Day } 1 \\
\text { Friday/Saturday } \\
(5 \mathrm{pm}-5 \mathrm{am})\end{array}$ & $\begin{array}{r}\text { Satur } \\
(5 \mathrm{p}\end{array}$ & $\begin{array}{l}\text { Inday } \\
\text { am) }\end{array}$ & $\begin{array}{c}\text { Day } 3 \\
\text { Sunday/Monday } \\
(5 \mathrm{pm}-5 \mathrm{am})\end{array}$ \\
\hline Collection time & $2 \mathrm{am}$ & & & $2 \mathrm{am}$ \\
\hline Location 1 & sample 1 & & & sample 8 \\
\hline Location 2 & sample 2 & & & sample 9 \\
\hline \multirow{2}{*}{ Location 3} & sample 3 & \multirow{2}{*}{\multicolumn{2}{|c|}{ sample 7}} & \multirow{2}{*}{ sample 10} \\
\hline & sample 4 & & & \\
\hline 2018 & $\begin{array}{c}\text { Day } 1 \\
\text { Friday/Saturday }\end{array}$ & Satur & Inday & \\
\hline Collection time & $4 \mathrm{am}$ & & & \\
\hline Location 1 & samples $1,2,3$ & & & \\
\hline Location 2 & samples 4,5 & sam & 8,9 & \\
\hline Location 3 & sample 6 & sam & 11 & \\
\hline Location 4 & - & & & \\
\hline
\end{tabular}


Table 2 Compounds detected in 18 pooled urine samples at the Split Ultra music festival in 2016 and 2017 by festival days

\begin{tabular}{|c|c|c|c|c|c|c|c|c|}
\hline \multirow{2}{*}{ Group } & \multirow{2}{*}{ Substances } & \multirow{2}{*}{ Substance class } & \multicolumn{3}{|c|}{$\begin{array}{ll}2016 \\
\text { Day }\end{array}$} & \multicolumn{3}{|c|}{$\begin{array}{l}2017 \\
\text { Day }\end{array}$} \\
\hline & & & 1 & 2 & 3 & 1 & 2 & 3 \\
\hline \multirow{25}{*}{$\begin{array}{l}\text { Classic } \\
(25)\end{array}$} & Nicotine & Stimulant & + & + & + & + & + & + \\
\hline & Cotinine & Stimulant & + & + & + & + & + & + \\
\hline & Theobromine & Stimulant & + & + & + & + & + & + \\
\hline & Caffeine & Stimulant & + & + & + & + & + & + \\
\hline & Amphetamine & Stimulant & + & & & & + & \\
\hline & MDEA (3,4-methylenedioxy-N-ethylamphetamine) & Stimulant & & & & + & + & \\
\hline & HMMA (4-hydroxy-3-methoxy-methamphetamine) & Stimulant & & & & + & & \\
\hline & MDMA (3,4-methylenedioxy-methamphetamine) & Stimulant & & + & + & + & + & + \\
\hline & $\begin{array}{l}\text { MDDMA (3,4-methylenedioxy-N, } \\
\text { N-dimethylamphetamine) }\end{array}$ & Stimulant & & & & + & & + \\
\hline & 3,4-MDA (3,4-methylenedioxyamphetamine) & Stimulant & & + & + & + & & + \\
\hline & pMMA (para-methoxyamphetamine) & Stimulant & & & & + & & \\
\hline & Propylhexedrine & Stimulant & + & + & & + & & + \\
\hline & Cocaine & Stimulant & & & & + & + & \\
\hline & Ecgonine methyl estere & Stimulant & + & & + & & + & \\
\hline & Cocaethylene & Stimulant & & & & & + & \\
\hline & Butabarbital & Hypnotic & + & + & & & & \\
\hline & Pentobarbital & Hypnotic & + & + & + & & & \\
\hline & D9-THC (delta-9-tetrahydrocannabinol) & Hallucinogen & + & + & & & & \\
\hline & Methadone & Opiate & + & & + & + & & \\
\hline & Oxymorphone & Opioid analgesic & & + & & & & \\
\hline & Tramadol & Opioid analgesic & & & + & & & + \\
\hline & Phenacetine & Analgesic & + & & & & & \\
\hline & Benzocaine & Local anesthetic & & + & & & & \\
\hline & Paracetamol & Antipyretic & + & + & + & + & + & + \\
\hline & Ibuprofen & $\begin{array}{l}\text { Nonsteroidal anti- } \\
\text { inflammatory drug }\end{array}$ & + & + & + & + & + & + \\
\hline \multirow{19}{*}{$\begin{array}{l}\text { NPS } \\
(19)\end{array}$} & Bk-MPA ( $\beta$-keto-methiopropamine) & Cathinone & & & & + & & + \\
\hline & 3,4-dimethylmethcathinone & Cathinone & + & + & + & + & & \\
\hline & 3,4-methylenedioxyphenyl-2-propanone & Cathinone & & & & + & & \\
\hline & Methedrone & Cathinone & + & & & & & \\
\hline & Mephedrone & Cathinone & & & & + & + & \\
\hline & Methylone & Cathinone & + & & & & & \\
\hline & Buphedrone & Cathinone & + & & & & & \\
\hline & Phenetylamine & Phenethylamine & & & & + & + & \\
\hline & 3-fluoromethamphetamine & Phenethylamine & & & & + & + & \\
\hline & 4-fluoromethamphetamine & Phenethylamine & & & + & + & + & \\
\hline & $\begin{array}{c}\text { Bk-MBDB ( } \beta \text {-keto-N- } \\
\text { methylbenzodioxolylbutanamine) } \\
\text { metabolite 3-OH-4-MeO }\end{array}$ & Phenethylamine & & & & + & + & \\
\hline & N-ethyl-N-hexylamphetamine & Phenethylamine & + & + & + & & & \\
\hline & N-hexyl, N-methylbezylamine & Phenethylamine & & & & + & & + \\
\hline & Ketamine & Anesthetic & & & & + & & \\
\hline & 1-benzylpiperazine & Piperazine & + & + & & & & \\
\hline & $5 \mathrm{MeO}$ DMT (5-methoxy-N,N-dimethyltryptamine) & Tryptamine & & + & & + & & \\
\hline & Psilocin & Tryptamine alkaloid & & & & + & & \\
\hline & N-ethyl-1,2-diphenylethylamine & Hallucinogen & + & & & & & \\
\hline & Salvinorin A & Hallucinogen & & + & & & & \\
\hline
\end{tabular}




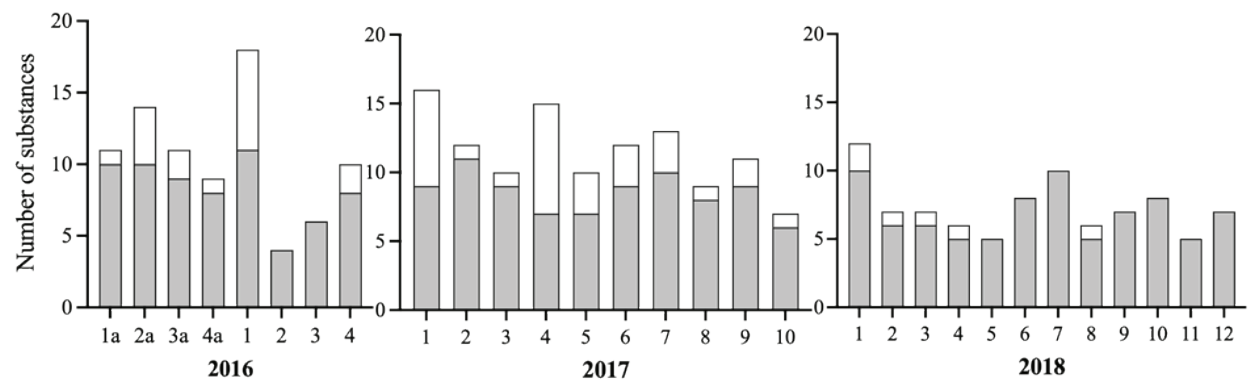

Figure 2 Number of classic and NPS drugs identified in urine samples during the Split Ultra music festival from 2016 to 2018 by sampling site (chemical toilet). 1a to $4 \mathrm{a}$ - samples taken from the toilet without added chemicals. NPS - new psychoactive substances

theobromine, paracetamol, ibuprofen, nicotine, and its metabolite cotinine (Table 2).

In the 12 samples collected in 2018, we identified 16 substances, 14 of which were classic and 2 NPS (from the cathinone and phenethylamine groups) (Table 3), most of which in sample 1 (10 and 2, respectively) taken from one of the toilets placed inside the stadium on the first day. In other urine samples 5 to 12 substances and metabolites were found. Seven samples had no NPS (Table 3 and Figure 2). Most of the classic substances and metabolites were from the stimulants group. As in the previous two years, all samples showed the presence of caffeine, theobromine, nicotine, and its metabolite cotinine. Cocaine was identified in six and MDMA in three urine samples. Ten of the 12 samples had ibuprofen (Table 3). The largest signal area (dominating over all other substances) was for MDMA in sample 12 (taken on the second day of the festival from the farthest toilet) and for cocaine in sample 7 (from the toilet located in the stadium ring). A higher cocaine signal was also found in all samples collected from the stadium toilet. In addition we identified methcathinone for the first time.

Table 3 Compounds detected in 12 pooled urine samples at the Split Ultra music festival in 2018 by festival days

\begin{tabular}{|c|c|c|c|c|c|c|c|c|c|c|c|c|c|c|}
\hline \multirow{4}{*}{ Group } & \multirow{4}{*}{ Substances } & \multirow{4}{*}{$\begin{array}{l}\text { Substance } \\
\text { class }\end{array}$} & \multicolumn{12}{|c|}{ Day } \\
\hline & & & \multicolumn{6}{|c|}{1} & \multicolumn{6}{|c|}{2} \\
\hline & & & \multicolumn{12}{|c|}{ Sample } \\
\hline & & & 1 & 2 & 3 & 4 & 5 & 6 & 7 & 8 & 9 & 10 & 11 & 12 \\
\hline \multirow{14}{*}{$\begin{array}{l}\text { Classic } \\
\text { (14) }\end{array}$} & Nicotine & Stimulant & + & + & + & + & + & + & + & + & + & + & + & + \\
\hline & Cotinine & Stimulant & + & + & + & + & + & + & + & + & + & + & + & + \\
\hline & Theobromine & Stimulant & + & + & + & + & + & + & + & + & + & + & + & + \\
\hline & Caffeine & Stimulant & + & + & + & + & + & + & + & + & + & + & + & + \\
\hline & $\begin{array}{l}\text { HMMA (4-hydroxy-3-methoxy- } \\
\text { methamphetamine) }\end{array}$ & Stimulant & + & & & & & + & & & & & & + \\
\hline & $\begin{array}{l}\text { MDMA (3,4-methylenedioxy- } \\
\text { methamphetamine) }\end{array}$ & Stimulant & & & & & & + & & & & + & & + \\
\hline & $\begin{array}{l}\text { MDDMA (3,4-Methylenedioxy- } \\
N, N \text {-dimethylamphetamine) }\end{array}$ & Stimulant & + & & & & & & & & & & & \\
\hline & $\begin{array}{l}\text { 3,4-MDA } \\
(3,4-m e t h y l e n e d i o x y a m p h e t a m i n e)\end{array}$ & Stimulant & & & & & & + & & & & & & \\
\hline & Cocaine & Stimulant & + & + & + & & & & + & & + & + & & \\
\hline & Ecgonine methyl ester & Stimulant & + & & + & & & & + & & + & + & & \\
\hline & Cocaethylene & Stimulant & & & & & & & + & & & & & \\
\hline & Mepivacaine & $\begin{array}{c}\text { Local } \\
\text { anaesthetic }\end{array}$ & + & + & & & & & & & & & & \\
\hline & Paracetamol & Antipyretic & & & & & & & + & & & & & \\
\hline & Ibuprofen & $\begin{array}{c}\text { Nonsteroidal } \\
\text { anti-inflammatory } \\
\text { drug }\end{array}$ & + & & & + & + & + & + & + & + & + & + & + \\
\hline \multirow{2}{*}{$\begin{array}{l}\text { NPS } \\
(2)\end{array}$} & Methcathinone & Cathinone & + & + & + & + & & & & + & & & & \\
\hline & 4-fluorometh-amphetamine & Phenethylamine & + & & & & & & & & & & & \\
\hline
\end{tabular}



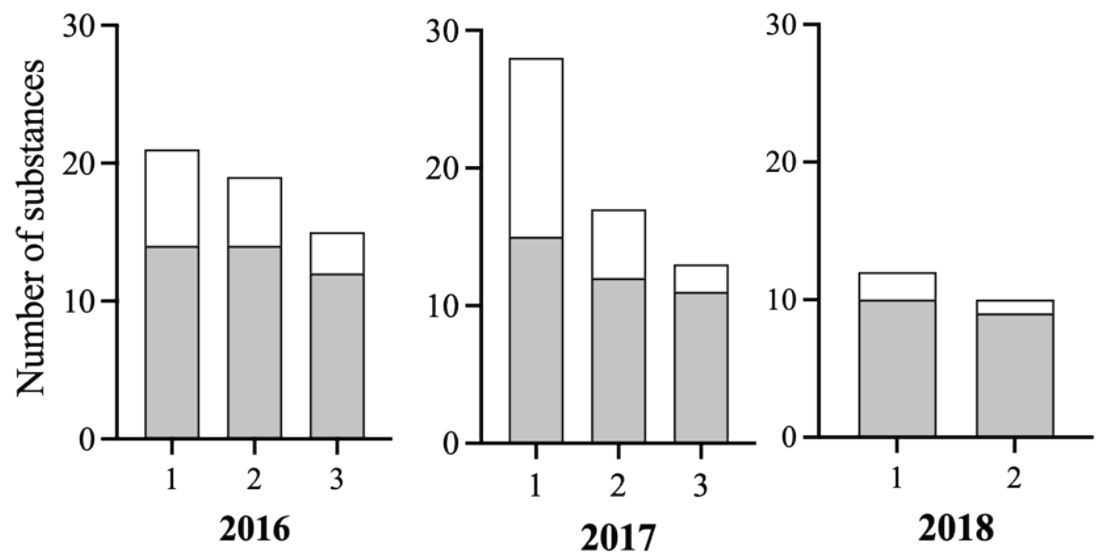

Figure 3 Number of classic and NPS drugs identified in urine samples during the Split Ultra music festival from 2016 to 2018 by festival day. NPS - new psychoactive substances

\section{DISCUSSION}

Quite expectedly, our findings reflect drug use trends at mass music events across Europe. The most prevalent were MDMA, propylhexedrine, and cocaine among the classic substances and cathinones and phenethylamines among the NPS. Similar results were reported by Bijlsma et al. (13), who analysed pooled urine and wastewater samples at six European music festivals in Spain from 2015 to 2018. They also reported a rising trend in ketamine use, while we noticed its continuous drop from year to year.

As for the NPS and the prevalence of cathinones and phenethylamines, our findings are in line with European reports of the time $(7,14,15)$, especially with those reporting a downward trend over the years, such as that of Archer et al. (16). In fact, in our study the prevalence of NPS in 2018 was ten times lower than in the two previous years. This is also in line with the European Monitoring Centre for Drugs and Drug Addiction (EMCDDA) report from 2018 about a decreasing trend in NPS availability in EU countries (17).

However, this downward trend does not undermine the issue at hand, as hospital care was provided to around 150 patients attending the Split festival alone over the three years of our study, fortunately with no fatal outcome. Altogether over 700 people were apprehended for possession, most of whom non-Croatian nationals. All of this calls for further monitoring at the Split and other similar music festivals across Europe to keep abreast with NPS accessibility and use trends.

\section{REFERENCES}

1. United Nations Office on Drugs and Crime, Early Warning Advisory on NPS, 2020 [displayed 23 October 2020]. Available at http://www.unodc.org/LSS/Page/NPS

2. Dargan PI, Wood DM, editors. Novel Psychoactive Substances: Classification, Pharmacology and Toxicology. $1^{\text {st }}$ ed. London: Elsevier - Academic Press; 2013.

3. European Monitoring Centre for Drugs and Drug Addiction (EMCDDA). New Psychoactive Substances in Europe. An Update From the EU Early Warning System, March 2015 [displayed 30 October 2020]. Available at https://www. emcdda.europa.eu/attachements.cfm/att_235958_EN_ TD0415135ENN.pdf

4. European Monitoring Centre for Drugs and Drug Addiction (EMCDDA). European Drug Report: Trend and Developments 2015 [displayed 30 October 2020]. Available at https://www. emcdda.europa.eu/system/files/publications/974/ TDAT15001ENN.pdf

5. Archer JH, Dargan PI, Hudson S, Wood DM. Analysis of anonymous pooled urine from portable urinals in central London confirms the significant use of novel psychoactive substances. QJM 2013;106:147-52. doi: 10.1093/qjmed/ hes 219

6. Archer JRH, Dargan PI, Hudson S, Davies S, Puchnarewicz M, Kicman AT, Ramsey J, Measham F, Wood M, Johnston A, Wood DM. Taking the Pissoir-a novel and reliable way of knowing what drugs are being used in nightclubs. J Subst Use 2014;19:103-7. doi: 10.3109/14659891.2012.740139

7. Kinyua J, Negreira N, Miserez B, Causanilles A, Emke E, Gremeaux L, de Voogt P, Ramsey J, Covaci A, van Nuijs ALN. Qualitative screening of new psychoactive substances in pooled urine samples from Belgium and United Kingdom. Sci Total Environ 2016;573:1527-35. doi: 10.1016/j. scitotenv.2016.08.124

8. Styszko K, Dudarska A, Zuba D. The presence of stimulant drugs in wastewater from Krakow (Poland): A snapshot. Bull 
Environ Contam Toxicol 2016;97:310-5. doi: 10.1007/ s00128-016-1869-5

9. Bertol E, Pascali J, Palumbo D, Catalani V, Di Milia M, Fioravanti A, Mari F, Vaiano F. 3-MeO-PCP intoxication in two young men: First in vivo detection in Italy. Forensic Sci Int 2017;274:7-12. doi: 10.1016/j.forsciint.2016.12.028

10. Vaiano F, Busardò FP, Palumbo D, Kyriakou C, Fioravanti A, Catalani V, Mari F, Bertol E. A novel screening method for 64 new psychoactive substances and 5 amphetamines in blood by LC-MS/MS and application to real cases. J Pharm Biomed Anal 2016;129:441-9. doi: 10.1016/j. jpba.2016.07.009

11. Rösner P, Junge T, Westphal F, Fritschi G. Mass Spectra of Designer Drugs. Weinheim: Wiley VCH; 2015.

12. SWGDRUG - Scientific Working Group for the Analysis of Seized Drugs. Mass Spectral Library [displayed 23 May 2018]. Available at http://www.swgdrug.org/ms.htm

13. Bijlsma L, Celma A, Castiglioni S, Salgueiro-González N, Bou-Iserte L, Baz-Lomba JA, Reid MJ, Dias MJ, Lopes A, Matias J, Pastor-Alcañiz L, Radonić J, Turk Sekulic M, Shine T, van Nuijs ALN, Hernandez F, Zuccato E. Monitoring psychoactive substance use at six European festivals through wastewater and pooled urine analysis. Sci Total Environ 2020;725:138376. doi: 10.1016/j.scitotenv.2020.138376

14. European Monitoring Centre for Drugs and Drug Addiction (EMCDDA). European Drug Report: Trend and Developments 2016 [displayed 30 October 2020]. Available at https://www. emcdda.europa.eu/system/files/publications/2637/ TDAT16001ENN.pdf

15. European Monitoring Centre for Drugs and Drug Addiction (EMCDDA). European Drug Report: Trend and Developments 2017 [displayed 30 October 2020] Available at https://www. emcdda.europa.eu/system/files/publications/4541/ TDAT17001ENN.pdf

16. Archer JRH, Mendes F, Hudson S, Layyne K, Dargan PI, Wood DM. Evaluation of long-term detection trends of new psychoactive substances in pooled urine from city street portable urinals (London, UK). Br J Clin Pharmacol 2020;86:517-27. doi: 10.1111/bcp.14239

17. European Monitoring Centre for Drugs and Drug Addiction (EMCDDA), 2019. European Drug Report: Trend and Developments 2018. [displayed 30 October 2020]. Available at https://www.emcdda.europa.eu/system/files/ publications/8585/20181816 TDAT18001ENN_PDF.pdf

\section{Nove psihoaktivne tvari u uzorcima urina prikupljenima tijekom Ultra Europe festivala u Splitu}

Analiza uzoraka urina prikupljenih iz prijenosnih kemijskih zahoda korisna je u otkrivanju droga za rekreaciju koje su se koristile tijekom Ultra Europe glazbenoga festivala. Zbog prisutnosti više od 150000 ljudi iz više od 150 svjetskih zemalja, moguće je dobiti više informacija o svjetskom trendu NPS-a. Analiza uzoraka urina koji su se prikupljali od 2016. do 2018. tijekom glazbenoga festivala Ultra Europe u Splitu provedena je radi otkrivanja prisutnosti novih psihoaktivnih tvari (NPS). Analizirano je trideset uzoraka urina prikupljenih iz prijenosnih kemijskih zahoda smještenih na mjestu festivala ili blizu njega. U 2016. godini prikupljeno je osam uzoraka urina iz dvaju zahoda koji su bili smješteni na dvama različitim mjestima, i to jedan s dodanim kemikalijama, a drugi bez njih. U 2017. godini prikupljeno je deset uzoraka urina iz triju zahoda na trima mjestima, svi iz zahoda s dodanim kemikalijama. U 2018. godini prikupljeno je dvanaest uzoraka urina iz devet prijenosnih kemijskih zahoda na četirima mjestima, svi s dodatkom kemikalija. Uzorci su kvalitativno analizirani tehnikom plinske kromatografije-spektrometrije masa (GC/MS) korištenjem načina ukupnog skeniranja. Podatci su uspoređeni s bazom spektara masa Wiley (DD2015), kao is vlastitom bibliotekom koja sadržava oko 1000 spojeva i metabolita. U analiziranim uzorcima pronađeno je 46 različitih tvari i metabolita, od kojih 26 klasičnih tvari/metabolita, uglavnom iz skupine stimulansa, te 20 tvari iz skupine novih psihoaktivnih tvari (NPS). U skupini NPS-a najviše ih je bilo iz skupina fenetilamina i katinona. U svakoj promatranoj godini, prvoga festivalskog dana otkriveno je više tvari nego u ostalim danima. Suprotno 2016. i 2017. godini, u 2018. godini broj otkrivenih tvari bio je znatno manji. Rezultati našeg istraživanja pokazali su stabilnost konzumacije klasičnih droga, ali su se trendovi NPS-a mijenjali.

KLJUČNE RIJEČI: amfetamini; droga za rekreaciju; glazbeni festival; katinoni; prijenosni kemijski zahod 